\title{
Hubungan antara Mathematics Teaching Efficacy Beliefs dan Mathematics Teaching Anxiety Mahasiswa PPL Program Studi Pendidikan Matematika
}

\author{
Hasanuddin, Erdawati Nurdin*, Hayatun Nufus, Arnida Sari \\ Pendidikan Matematika, Universitas Islam Negeri Sultan Syarif Kasim Riau \\ e-mail : *erdawati.nurdin@uin-suska.ac.id
}

\begin{abstract}
ABSTRAK. Penelitian ini bertujuan untuk melihat hubungan antara Mathematics Teaching Efficacy Beliefs dan Mathematics Teaching Anxiety mahasiswa Praktik Pengalaman Lapangan program studi matematika FTK UIN Suska Riau. Populasi penelitian adalah seluruh mahasiswa Program Studi Pendidikan Matematika yang sedang melaksanakan Praktik Pengalaman Mengajar (PPL). Teknik pengambilan sampel ini adalah non probability sampling, yaitu sampel jenuh. Sample data penelitian ini adalah sebanyak 77 orang. Data yang diperoleh dikumpulkan melalui angket. Teknik analisis yang digunakan adalah teknik korelasi product moment. Berdasarkan analisa data, diketahui bahwa tidak terdapat hubungan negatif antara mathematics teaching efficacy beliefs dan mathematics teacbing anxiety pada mahasiswa PPL Program Studi Pendidikan Matematika FTK UIN suska Riau.
\end{abstract}

Kata Kunci: Program Pengalam Lapangan, Mathematics Teacbing Efficacy Beliefs, Mathematics Teaching Anxiety

\section{PENDAHULUAN}

Guru merupakan komponen utama dalam pendidikan. Profesionalisme guru diatur dalam UU No. 14 Tahun 2005 tentang Guru dan Dosen. Dalam UU tersebut dinyatakan bahwa guru adalah pendidik profesional dengan tugas utama mendidik, mengajar, membimbing, mengarahkan, menilai dan mengevaluasi peserta didik pada berbagai jenjang dan jenis pendidikan formal. Untuk menjamin keterlaksanaan tugas utamanya, guru wajib memiliki kualifikasi akademik, kompetensi, sertifikat pendidik, sehat jasmani dan rohani, serta memiliki kemampuan untuk mewujudkan tujuan pendidikan nasional.

Salah satu faktor yang menjadi kunci keberhasilan sistem pendidikan nasional adalah sistem pendidikan guru (Astuti, Suhandana \& Dantes, 2013). Kurikulum pendidikan guru terdiri atas tiga komponen yaitu pendidikan umum, spesialisasi dan profesional. Model pendidikan tersebut juga dilaksanakan oleh Fakultas Tarbiyah dan Keguruan (FTK) Uniersitas Islam Negeri Sultan Syarif Kasim Riau sebagai Lembaga Pendidik Tenaga Kependidikan (LPTK). Upaya mendidikan calon guru dilakukan dengan memberi kesempatan kepada mahasiswa untuk melaksanakan praktik pengalaman Lapangan (PPL).

Pada saat pelaksanaan, mahasiswa PPL perlu memadukan antara penguasaan materi dan praktik (Astuti, Suhandana \& Dantes,, 2013). Penguasan materi menjadi wajib bagi mahasiswa PPL. Di lain pihak, penguasan praktik berkaitan erat dengan penguasan ilmu pendidikan. 
Seringkali mahasiswa PPL hanya memiliki sedikit pengetahuan tentang filosofi pendidikan, kebanyakan mereka tidak mempelajari behaviorisme dan konstruktivisme secara mendalam (Ennis-cole, n.d.).

Penguasaan materi memilki kaitan erat dengan kecemasan matematika (Furner \& Gonzalez-dehass, 2011). Dengan kala lain, kurangnya penguasaan materi berdampak pada timbulnya kecemasan matematika bagi mahasiswa PPL. Sementara itu, kecemasan matematika berkaitan erat dengan kecemasan mengajar matematika (Mathematics Teaching Anxiety) (Peker \& Ertekin, 2011).

Ngidi \& Sibaya (2003) menemukan kertaikatan antara kecemasan mengajar matematika terhadap praktik mengajar. Kajian lain yang berkaitan kecemasan matematika yaitu tingkat kecemasan matematika guru praktik SD (Catlioglu et al., 2009). Beberapa studi pendahuluan tentang kecemasan mengajar matematika telah dikaji oleh para ahli antara lain relasi gender terhadap kecemasan mengajar matematika (Peker, Halat \& Mirasyedioglu, 2010). Ada hubungan antara kecemasan mengajar matematika dan keyakinan (beliefs) epistimologis mahasiswa PPL berbanding terbalik (Ertekin et al., 2010).

Keyakinan (beliefs) umum tentang matematika, antara lain: matematika adalah perhitungan, masalah matematika harus diselesaikan kurang dari tiga menit, tujuan mengerjakan soal matematika adalah untuk mendapatkan jawaban benar (Spangler, 1990). Lebih jauh lagi, keyakinan matematika dapat dikaitkan dengan keberhasilan (efficacy) praktik mengajar. (Catlioglu et al., 2009). Berdasarkan pemaparan tersebut, terdapat kemungkinan adanya keterkaitan antara keyakinan (belief) tentang matematika dan keberhasilan (efficacy) praktik mengajar dengan kecemasan mengajar matematika (mathematics teaching anxiety). Oleh sebab itu, dalam tulisan ini akan mengkaji mengenai hubungan antara variabel kecemasan mengajar matematika dan keyakinan keberhasilan mengajar matematika mahasiswa PPL Program Studi Pendidikan Matematika.. Adapun rumusan masalah yang diajukan pada penelitum ini adalah apakah terdapat hubungan antara Mathematics Teaching Efficacy Beliefs dan Mathematics Teaching Anxiety mahasiswa PPL Program Studi Pendidikan Matematika?.

\section{TINJUAN LITERATUR}

\section{Kecemasan}

Kecemasan berasal dari bahasa latin anxius, yaitu kata yang digunakan untuk mendeskripsikan efek negatif dan rangsangan fisiologis. Menurut Atkinson et al. (1999) kecemasan merupakan keadaan mental yang tidak enak berkenaan dengan rasa takut yang mengancam yang ditandai dengan perasaan khawatir, ketidakenakan dan perasaan yang tidak mampu untuk dihindari oleh seseorang. Kecemasan merupakan suatu perasaan khawatir pada seseorang yang mengeluhkan mengenai kemungkinan akan terjadinya suatu kejadian buruk.

Kecemasan berbeda dengan takut, yang merupakan respon nyata terhadap ancaman (American Psychiatric Association, 2013). Walaupun kecemasan timbul akibat adanya ancaman yang akan terjadi. Kecemasan bisa juga dipandang sebagai suatu keadaan emosi yang tidak menentu, takut, khawatir dan merasa sulit, biasanya muncul akibat reaksi berlebihan terhadap situasi yang secara subjektif seakan- akan mengancam (Bouras \& Holt, 2007). Berdasarkan pendapat pendapat ahli tersebut maka dapat dikatakan bahwa kecemasan adalah keadaan emosi yang tidak menyenangkan akan kemungkinan terjadi sesuatu yang buruk di masa depan.

Menurud Freud dalam Supratiknya (1993) kecemasan terdiri dari tiga jenis yaitu: a) kecemasan realitas, yaitu rasa takut akan bahaya yang nyata di dunia luar, b) kecemasan neurotik, yaitu rasa takut dihukum akibat pemuasan insting pribadi, dan c) kecemaasan mental, yaitu rasa takut terhadap suara hati. Faktor yang penyebab munculnya kecemasan menurut Beck, Emery dan Grenberg dalam Wolman (1994), antara lain: a) genetik, yaitu faktor bawaan sejak lahir, b) trauma mental, yaitu ketakutan akan terjadi hal yang tidak mengenakkan, dan c) pikiran irasional, asumsi dan kesalahan proses kognitif. 
Terdapat dua sumber kecemasan ada, yaitu sumber internal dan sumber eksternal. Faktor internal misalnya perasaan tidak mampu, tidak percaya diri, persaan bersalah atau kurangnya penglaaman dalam menghadapi berbagai kemungkinan (Qrutch dalam Hartati \& Dwijayanti, 1997). Faktor Eksternal antara lain berupa penolakan sosial, kiritikan dan beban tugas kerja yang berlebihan.

\section{Praktik Pengalaman Lapangan.}

Praktik adalah pelaksanaan secara nyata apa yang disebut dalam teori (KBBI, 2005, p.892). Praktik merupakan suatu pelaksanaan dari teori dalam keadaan nyata. Hal ini sesuai dengan Kamaruddin (2006, p.200) yang menyatakan bahwa praktikum merupakan cara melaksanakan dalam keadaan nyata apa yang dikemukakan dalam teori. PPL merupakan kegiatan kurikuler yang wajib dilaksanakan oleh mahasiswa praktikan. Teori yang telah diperoleh pada semester sebelumnya diterapkan langsung dalam pembelajaran di sekolah. Tujuannya adalah agar mahasiswa praktikan mendapat pengalaman dan keterampilan dalam menyelenggarakan pendidikan. PPL yang dilaksanakan oleh mahasiswa mencakup latihan mengajar dan tugas-tugas kependidikan di luar mengajar secara terbimbing dan terpadu.

Menurut Hamalik (2009, p.171) bahwa PPL adalah serangkaian kegiatan yang diprogramkan bagi mahasiswa LPTK, yang meliputi baik latihan mengajar maupun latihan di luar mengajar. PPL merupakan mata kuliah wajib di FTK UIN Suska Riau. Kegiatan ini dilaksanakan setelah mahasiswa menyelesaikan mata kuliah microteaching. Kegiatan PPL ini difungsikan sebagai wadah untuk membentuk dan membina kompetensi-kompetensi profesional pekerjaan pendidik dan tenaga kependidikan. Selain itu, melalui kegiatan ini, mahasiswa berlatih untuk menerapkan teori proses belajar mengajar dalam skala kecil, bersifat artificial sebagai simulasi dari proses mengajar sesungguhnya. Tujuan lain dari pelaksanaan kegiatan PPL yaitu untuk memberikan pengalaman belajar bagi mahasiswa dalam hal pengalaman mengajar, memperluas wawasan, melatih dan mengembangkan kompetensi yang diperlukan dalam bidangnya, meningkatkan keterampilan, kemandirian, tanggung jawab dan kemampuan dalam memecahkan masalah.

\section{Mathematics Anxiety}

Selain menjadi salah satu konsep yang paling banyak diteliti akhir-akhir ini, mathematics anxiety (kecemasan matematika) telah mempengaruhi semua aspek pendidikan matematika secara langsung maupun tidak langsung (Catlioglu et al., 2009). Hanya saja, tidak ada konsensus secara umum di kalangan para peneliti mengenai definisi dan dimensi mathematics anxiety tetapi juga mengenai penyebab dan dampaknya. Vinson (2001) berpendapat bahwa kecemasan matematika lebih dari ketidaksukaan terhadap matematika (p.89). Jika definisi tetap diperlukan, maka Suinn \& Winson (2003) menyatakan bahwa kecemasan matematika melibatkan perasaan ketegangan dan kecemasan yang mengganggu manipulasi angka dan pemecahan masalah matematika dalam berbagai kehidupan biasa dan situasi akademik (p.551). Dengan demikian, harus dipandang dari perspektif yang lebih besar dalam rangka membangun kompleksitas teorinya "afektif, respon perilaku dan kognitif dengan ancaman terhadap harga diri yang terjadi sebagai respon terhadap situasi yang melibatkan matematika" (Atkinson et al., 1988, p. 18). Hal ini dinyatakan bahwa "perasaan cemas dapat menyebabkan panik, ketegangan, tidak berdaya. takut, tertekan, malu, ketidakmampuan untuk mengatasi, telapak tangan berkeringat, perut gugup, kesulitan bemapas dan kehilangan kemampuan untuk berkonsentrasi" (Cemen, 1987; Stepelman, 1990, p. 210; dikutip di Trujillo \& Hadfield (1999, p.219). Di sisi lain, mungkin menghasilkan beberapa efek positif untuk beberapa kasus. Menurut hasil penelitian eksplorasi mathematic anxiety dengan menggunakan meta-analisis, Hembree (1990) menyatakan bahwa mathematic anxiety telah dikaitkan dengan kinerja yang buruk pada tes prestasi matematika dan penghindaran subjek serta sikap positif terhadap matematika. Ia menemukan bahwa variabel-variabel seperti kemampuan, tingkat kelas sekolah dan bidang kajian pada tingkat, dengan guru praktik aritmatika sangat rentan terhadap kecemasan matematika (p. 33). 


\section{Mathematics Teaching Anxiety}

Setiap mahasiswa dalam program pendidikan guru wajib mengikuti praktik pengalaman lapangan. Fungsi praktik mengajar yaitu sebagai pengenalan awal bagi calon guru terhadap lingkungan mengajar (sekolah/madarasah) yang sesungguhnya di dunia nyata. Beberapa penelitian menunjukkan bahwa terdapat mahasiswa yang mengalami kecemasan terhadap praktik mengajar (Behets, 1990; Mcbride, 1981; Wendt \& Bain, 1989).

Temuan penelitian lain menunjukkan bahwa kontrol kelas dan gangguan kelas memiliki kontribusi terhadap tingginya tingkat kecemasan mahasiswa saat menghadapi praktik mengajar. Penelitian yang dilakukan oleh Preece (1979, p. 18) menemukan adanya korelasi antara kecemasan guru praktik dan masalah kontrol kelas. Hart (1987, p.16) juga menyampaikan korelasi positif antara kecemasan guru praktik dan gangguan kelas. Oleh karena itu, kecemasan tampaknya menjadi karakteristik yang relevan dari guru praktik. Sejumlah penelitian di berbagai negara telah menunjukkan sejauh mana guru praktik mengalami kecemasan terkait dengan praktik mengajar. Beberapa studi menunjukkan bahwa guru praktik mengalami tingkat kecemasan sedang (Hart, 1987; Behets, 1990; Wendt \& Bain, 1989). Sementara yang lain menunjukkan bahwa guru praktik menunjukkan tingkat kecemasan yang tinggi (Bradley, 1984).

Beberapa studi juga telah memperlihatkan bahwa sifat kecemasan mahasiswa praktik yang berkaitan dengan praktik mengajar. Hasil penelitian menunjukkan bahwa mahasiswa guru praktik mengalami kecemasan berdasarkan faktor-faktor seperti evaluasi, murid dan keprihatinan profesional, kontrol kelas dan persyaratan praktik mengajar (Hart, 1987). Di Kanada, Morton et al. (1997) melaporkan bahwa kecemasan mahasiswa calon guru berkaitan dengan evaluasi, pedagogik, manajemen kelas dan hubungan faktor staf sekolah. Capel (1997) melaporkan hasil penelitiannya bahwa di antara kecemasan mahasiswa praktik di Canterbury disebabkan oleh evaluasi, persiapan profesional, kelas kontrol, dan faktor staf sekolah. Terutama, faktor kecemasan mahasiswa praktik yang berkaitan dengan praktik mengajar yang umum di banyak negara. Studi ini juga mengungkapkan bahwa mahasiswa praktik di seluruh dunia cemas tentang evaluasi. Para peneliti telah mencatat bahwa persepsi mahasiswa guru mengenai sumber kecemasan terkait dengan praktik mengajar dapat sangat bervariasi dari individu ke individu lainnya. Mereka lebih lanjut menyatakan bahwa ada reaksi ferential-beda terhadap stres sebagai fungsi dari variabel seperti kepribadian, budaya atau bahkan jenis kelamin (Fontana \& Abouserie, 1993). Dalam sebuah studi tentang mahasiswa praktik yang sedang kuliah di fakultas pendidikan di Universitas Kanada diamati bahwa perempuan mengalami kecemasan lebih tinggi dibandingkan laki-laki sebelum praktik mengajar (Morton et al., 1997).

\section{Mathematics Teaching Efficacy Beliefs}

Istilah self-efficacy pertama kali diperkenalkan oleh Albert Bandura. Seorang ahli di bidang teori pembelajaran sosial. Self efficacy dapat diartikan sebagai penilaian individual tentang seberapa baik seseorang dapat mengatur dan mengeksekusi pembelajaran yang diperlukan untuk mencapai suatu tujuan (Albayrak \& Unal, 2011). Menurut Frost (2012, p. 3) guru atau pegajar yang memiliki keyakinan kuat tentang efficacynya akan tabah, mampu menyelesaikan masalah dan yang lebih penting adalah mampu belajar dari pengalamannya. Keyakinan yang kuat tersebut disebut sebagai efficacy beliefs.

Efficacy beliefs jika dikaitkan dengan pengajaran matematika, maka muncul istilah mathematics teaching efficacy beliefs. Definisi mathematics teaching efficacy beliefs adalah gambaran perasaan seseorang mengenai kemampuannya untuk mengajarkan matematika ke siswa (Sullivan, 2006). Mathematics teaching efficacy beliefs terdiri dari dua bagian yaitu personal mathematics teaching efficacy (PMTE) dan mathematics teaching outcome epectancy (MTOE) (Enoch, Smith \& Huinker, 2000). PMTE secara khusus mengukur konsep diri pengajar mengenai kemampuannya mengajar matematika secara efektif. Sedangkan MTOE secara khusus mengukur keyakinan pengajar mengenai kemampuannya mempengaruhi secara langsung capaian pembelajaran siswa. 


\section{METODE PENELITIAN}

Penelitian ini merupakan penelitian survey yang melibatkan 77 orang mahasiswa Program Studi Pendidikan Matematika UIN Sultan Sayrif Kasim Riau. Populasi penelitian ini adalah seluruh mahasiswa Program Pengalaman Lapangan (PPL) yang bejumlah 79 orang. Teknik pengambilan sampel yang digunakan adalah nonprobability sampling, yaitu sampling jenuh, dimana semua anggota populasi menjadi sampel. Dari 79 sampel setelah dilakukan pemeriksaan hanya 77 sampel yang memenuhi syarat. Teknik pengumpulan data yang digunakan adalah teknik angket. Terdapat dua angket yang digunakan, yaitu angket untuk mengukur tingkat mathematics teaching efficacy beliefs (MTEB) dan angket mathematics teaching anxiety (MTA). Angket yang digunakan disusun berdasarkan skala Likert dengan 5 kategori, dari sangat tidak setuju hingga setuju sekali. Data yang diperoleh melalui angket kemudian dianalisis secara deskriptif. Uji korelasi product moment dilakukan untuk melihat adakah hubungan negatif antara mathematics teaching efficacy beliefs dengan mathematics teaching anxiety mahasiswa PPL Program Studi Pendidikan Matematika FTK UIN Suska Riau. Dalam artian, semakin tinggi mathematics teaching efficacy beliefs maka tingkat mathematics teaching anxiety semakin rendah. Sebaliknya, Semakin rendah mathematics teaching efficacy beliefs maka tingkat mathematics teaching anxiety semakin tinggi.

Adapun hipotesis yang diajukan dalam penelitian ini adalah:

Ho : Tidak terdapat hubungan negatif antara mathematics teaching efficacy beliefs dengan mathematics teaching anxiety mahasiswa PPL Program Studi Pendidikan Matematika FTK UIN Suska Riau.

$\mathrm{Ha}$ : Terdapat hubungan negatif antara mathematics teaching efficacy beliefs dengan mathematics teaching anxiety mahasiswa PPL Program Studi Pendidikan Matematika FTK UIN Suska Riau.

\section{TEMUAN DAN DISKUSI}

\section{Hasil Penelitian}

Sebagimana telah disebutkan bahwa sampel yang mengembailikan angket sebanyak 77 orang, sehingga analisis data dilakukan berdasarkan isian dari 77 sampel tersebut. Sebelum melakukan uji statistik, maka berikut diberikan deskripsi data mathematics teaching efficacy beliefs dan mathematics teaching anxiety.

Tabel 1. Deskripsi variabel MTEB dan MTA

\begin{tabular}{|c|c|c|c|c|c|}
\hline & $\mathrm{N}$ & Minimum & Maksimum & Mean & Std. Deviation \\
\hline MTEB & 77 & 68 & 90 & 79.05 & 4.634 \\
\hline MTA & 77 & 36 & 82 & 56.36 & 8.975 \\
\hline $\begin{array}{l}\text { Valid } \\
\text { (listwise) }\end{array}$ & 77 & & & & \\
\hline
\end{tabular}

Sebelum Analisa data dilakukan perlu dilakukan uji normalitas sebaran pada kedua variabel penelitian, baik variabel bebas maupun variabel terikatnya. Selanjutnya dilakukan uji linieritas untuk mengetahui bentuk korelasi antara masing-masing variabel.

Untuk mengetahui apakah data sudah menyebar secara normal, perlu dilakukan uji normalitas. Salah satu uji normalitas yang digunakan adalah uji Shapiro-Wilk. Uji Shapiro-Wilk digunakan karena data yang akan diuji adalah data ordinal. Data dikatakan normal apabila harga $\rho>0.05$. Pada penelitian ini diperoleh harga $\rho=0.490$ untuk mathematics teaching efficacy beliefs dan $\rho=0.575$ untuk mathematics teaching anxiety. Hasil ini menunjukkan baik mathematics teaching efficacy beliefs maupun mathematics teaching anxiety terdistribusi normal.

Selanjutnya dilakukan uji linieritas untuk mengetahui bentuk korelasi antara masingmasing variabel. Linieritas hubungan antara mathematics teaching elficacy beliefs dan mathematics teaching anxiety dapat diketahui melalui uji linieritas. Uji linieritas hubungan dapat diketahui dengan menerapkan teknik grap interaktif yang menghasilkan diagram pencar dengan analisa varians. Adapun hasil pengujiannya dapat dilihat pada tabel berikut: 
Tabel 2. Tabel Analisis Varians

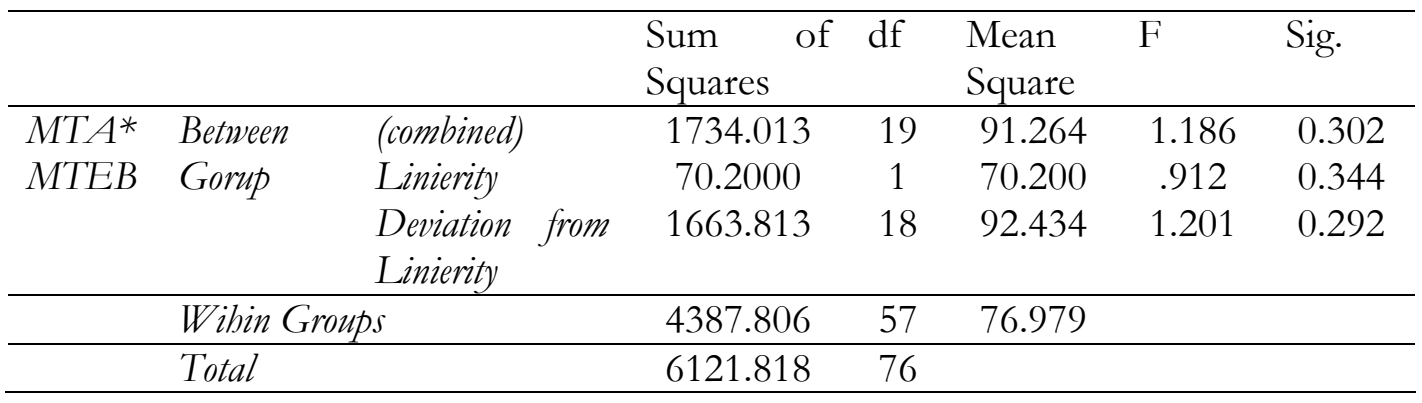

Berdasarkan pada Tabel 2 dapat dilihat hubungan mathematics teaching efficacy beliefs dan mathematics teaching anxiety tidak linier, hal ini dapat dilihat dari nilai signifikassi linieritasnya yaitu 0.344 lebih besar dari 0.05 .

\section{Analisa Data}

Hipotesis yang akan diuji pada peneltian ini adalah apakah terdapat hubungan negatif yang signifikan antara mathematics teaching efficacy beliefs dan mathematics teaching anxiety beliefs. Maknanya adalah semakin tinggi keyakinan kemampuan mengajar matematika maka semakin tendah tingkat kecemasan mengajar matematikanya, sebaliknya semakin rendah tingkat kepercayan kemampuan mengajar matematikanya maka semakin tinggi tingkat kecemasan mengajar matematikanya.

Rumusan hipotesa diperlukan dalam pengujian statistik. Adapun hipotesa statistik dalam penelitian ini, yaitu:

Ho: $\rho=0$, Ha: $\rho>0$

Hipotesa nol (Ho) berarti bahwa tidak terdapat hubungan antara mathematics teaching efficacy beliefs dan mathematics teaching anxiety pada mahasiswa PPL Program Studi Pendidikan Matematika FTK UIN Suska Riau. Sebaliknya, hipotesa alternatifnya $(\mathrm{Ha})$ berarti terdapat hubungan antara mathematics teaching efficacy beliefs dan mathematics teaching Anxiety pada mahasiswa PPL Program Studi Pendidikan Matematika FTK UIN Suska Riau. Berdasarkan pada tujuan penelitian, maka perlu dilakukan analisa statistik dengan menggunakan uji korelasi pearson. Adapu hasil uji statistik dapat dilihat pada Tabel 3.

Tabel. 3. Korelasi Product Moment

\begin{tabular}{llcc}
\hline B & & MTEB & MTA \\
\hline MTEB & Pearson Correlation & 1 & -0.107 \\
& Sign (2-tailed) & & 0.354 \\
& N & 77 & 77 \\
\hline MTA & Pearson Correlation & -0.107 & 1 \\
& Sign (2-tailed) & 0.354 & \\
& N & 77 & 77 \\
\hline
\end{tabular}

Hasil uji statistik seperti yang dilihat pada Tabel 3 diperoleh dengan mengunakan program SPSS. Berdasarkan Tabel 2 diperoleh nilai $\mathrm{r}$ hitung sebesar -0.107 dengan tingkat signifikansi 0.01 untuk korelasi antara mathematics teaching efficacy beliefs dan mathematics teaching anxiety pada mahasiswa PPL Program Studi Pendidikan Matematika UIN Suska Riau. Hal tersebut menunjukan bahwa hipotesis nol (Ho) diterima. Artinya tidak terdapat hubungan negatif yang signifikan antara mathematics teaching efficacy beliefs dan mathematics teaching anxiety pada mahasiswa PPL FTK UIN Suska Riau.

Berdasarkan data penelitian, dapat dilakukan kategorisasi yang didasarkan pada asumsi bahwa skor populasi terdistribusi normal. Berikut diuraikan gambaran masing-masing skor mathematics teaching efficacy beliefs dan mathematics teaching anxiety dan kategorinya. 


\section{Gambaran skor mathematics teaching efficacy beliefs}

Skala mathematics teaching efficacy beliefs terdiri dari 23 item dengan lima pilihan jawaban yang bergerak dari 1 sampai 5. Berdasarkan skala tersebut diperoleh gambaran skor empirik dan skor hipotetiknya.

Tabel.4 Deskripsi Skor Empirik dan Hipotetif MTEB

\begin{tabular}{lccccc}
\hline & $\mathrm{N}$ & Minimum & Maksimum & Mean & Std. Deviation \\
\hline Empirik & 77 & 68 & 90 & 79.05 & 4.634 \\
\hline Hipotetik & 77 & 23 & 115 & 69.00 & 15.333 \\
\hline
\end{tabular}

Pada Tabel 4 dapat dilihat hasil perbandingan mean empirik dan mean hipotetik dari variabel mathematics teaching efficacy beliefs yang menunjukkan $\mu \mathrm{E}>\mu \mathrm{H}$,yaitu W $79.05>69.00$ sehingga dapat disimpulkan bahwa skor mathematics teaching efficacy lebih tinggi daripada mathematics teaching efficacy pada populasi.

Selanjutnya, akan disusun kategorisasi mathematics teaching efficacy beliefs sesuai dengan tingkatan rendah, sedang dan tinggi. Adapun aturan dalam menentukan kategori sebagai berikut:

1. Rendah, jika skor MTEB kurang dari mean -1(SD)

2. Sedang, jika skor MTEB diantara mean - 1 (SD) dan mean +1 (SD)

3. Tinggi, jika skor MTEB di atas mean +1 (SD)

Data kategorisasi diperoleh dengan memperhatikan nilai mean empirik sebesar 79.05 dan standar deviasi sebesar 4.634 maka kriteria kategorisasi untuk variabel mathematics teaching efficacy beliefs pada mahasiswa PPL Program Studi Pendidikan Matematika FTK UIN Suska Riau dapat dilihat pada tabel berikut:

Tabel 5. Kategorisasi MTEB

\begin{tabular}{cccccc}
\hline & & Frequency & Percent & Valid Percent & Cumulative Percent \\
\hline Valid & Tinggi & 12 & 16.6 & 15.6 & 15.6 \\
& Sedang & 52 & 67.5 & 67.5 & 83.1 \\
& Rendah & 13 & 16.9 & 16.9 & 100.0 \\
& Total & 77 & 100.0 & 100.0 & \\
\hline
\end{tabular}

Berdasarkan Tabel 5. dapat diketahui bahwa sebahagian besar mahasisw PPL Program Studi Pendidikan Matematika UIN Suska Riau memiliki mathematics teaching eficacy beliefs sedang yaitu sejumlah 52 orang $(67.5 \%)$. Sedangkan 12 orang (15.6\%) diantaranya masuk kategori tinggi dan 13 orang $(16,9 \%)$ memiliki masuk pada kategori rendah.

\section{Gambaran skor mathematics teaching anxiety}

Skala mathematics teaching anxiety terdiri dari 25 item dengan 5 pilihan jawaban yang bergerak dari 1 sampai 5. Berdasarkan skala tersebut diperoleh gambaran skor empirik dan skor hipotetiknya.

Tabel 6. Deskripsi Skor Empirik dan Hipotetif MTA

\begin{tabular}{lccccc}
\hline & N & Minimum & Maksimum & Mean & $\begin{array}{c}\text { Std. } \\
\text { Deviation }\end{array}$ \\
\hline Empirik & 77 & 36 & 82 & 56.36 & 8.975 \\
Hipotetik & 77 & 25 & 125 & 75.00 & 16.667 \\
\hline
\end{tabular}

Pada Tabel 6 dapat dilihat hasil perbandingan mean empirik dan mean hipotetik dari variabel mathematics teaching anxiety yang menunjukkan $\mu \mathrm{E}<\mu \mathrm{H}$ yaitu $79.05<69.00$ sehingga dapat disimpulkan bahwa skor mathematics teaching anxiety lebih rendah daripada mathematics teaching anxiety pada populasi. Data kategorisasi diperoleh dengan memperhatikan nilai mean empirik sebesar 56.36 dan standar deviasi sebesar 8.975 maka kriteria kategorisasi untuk variabel mathematics teaching anxiety pada mahasiswa PPL Program Studi Pendidikan Matematika FTK UIN Suska Riau dapat dilihat pada tabel berikut: 
Tabel 7. Kategorisasi MTA

\begin{tabular}{cccccc}
\hline & & Frequency & Percent & $\begin{array}{c}\text { Valid } \\
\text { Percent }\end{array}$ & $\begin{array}{c}\text { Cumulative } \\
\text { Percent }\end{array}$ \\
\hline Valid & Tinggi & 9 & 11.7 & 11.7 & 11.7 \\
& Sedang & 57 & 74.0 & 74.0 & 85.7 \\
& Rendah & 11 & 14.3 & 14.3 & 100.0 \\
& Total & 77 & 100 & 100.0 & \\
\hline
\end{tabular}

Berdasarkan Tabel 7 dapat dilihat bahwa sebagian besar mahasiswa PPL Program Studi Pendidikan Matematika UIN Suska Riau memiliki mathematics teaching anxiety sedang yaitu sejumlah 57 orang $(74.5 \%)$. Sedangkan 9 orang $(11.7 \%)$ diantaranya masuk kategori tinggi dan 11 orang $(14.3 \%)$ memiliki masuk pada kategori rendah.

\section{Gambaran skor mathematics teaching efficacy beliefs berdasarkan jenis kelamin}

Pada bagian ini dipaparkan mengenai gambaran skor teaching efficacy beliefs berdasarkan jenis kelamin, dapat di lihat pada tabel berikut:

Tabel 8. Deskripsi Skor MTEB berdasarkan Jenis Kelamin

\begin{tabular}{cccccc}
\hline Variabel & \multicolumn{5}{c}{ Skor Empirik } \\
\cline { 2 - 6 } & $\mathrm{N}$ & Min & Maks & Mean & SD \\
Laki-laki & 16 & 72 & 84 & 79.31 & 3.114 \\
Perempuan & 62 & 68 & 90 & 78.98 & 4.975 \\
\hline
\end{tabular}

Berdasarkan Tabel 8 dapat dilihat skor mathematics teaching efficacy beliefs berdasarkan jenis kelamin. Mean score subjek yang berjenis kelamin laki-laki (79.31) lebih tinggi dibanding mean score yang berjalan kelamin perempuan (78.98). Untuk melihat apakah terdapat perbedaan yang signifikan antara mathematics teaching efficacy beliefs mahasiswa perempuan dan laki-laki maka dilakukan uji analisis varians.

Tabel 9. Uji Analis Varians Skor MTEB berdasarkan Jenis Kelamin

\begin{tabular}{cccccc}
\hline MTEB & \multicolumn{7}{c}{ S } & & \\
\hline & Sum of squares & df & Mean Square & F & Sig \\
Between Groups & 1.371 & 1 & 1.371 & 0.063 & 0.802 \\
Within Groups & 1630.421 & 75 & 21739 & & \\
Total & 1631.792 & 76 & & & \\
\hline
\end{tabular}

Perbedaan mathematics teaching efficacy beliefs antara subjek yang berjenis kelamin laki-laki dan perempuan dapat dilihat pada Tabel 9. Adapun mathematics teaching efficacy beliefs antara subjek berjenis kelamin laki-laki dan perempuan tidak memiliki perbedaan yang signifikan $(\rho=0,802$ $>\alpha=0.05)$. Artinya, baik mahasiswa ataupun mahasiswa memiliki tinngkat mathematics teaching eficacy belief yang tidak berbeda secara signifikan.

\section{Gambaran skor mathematics teaching anxiety beliefs berdasarkan jenis kelamin}

Pada bagian ini dipaparkan mengenai skor mathematics teaching anxiety berdasarkan jenis kelamin. Deskripsi skor mathematics teaching anxiety berdasarkan jenis kelamin dapat dilihat pada tabel berikut:

Tabel 10. Deskripsi Skor MTA berdasarkan Jenis Kelamin

\begin{tabular}{lccccc}
\hline Variabel & \multicolumn{5}{c}{ Skor Empirik } \\
\cline { 2 - 6 } & $\mathrm{N}$ & Min & Maks & Mean & SD \\
Laki-laki & 16 & 36 & 68 & 54.56 & 9.302 \\
Perempuan & 61 & 37 & 82 & 56.84 & 8.905 \\
\hline
\end{tabular}


Berdasarkan Tabel 10 dapat dilihat skor mathematics teaching anxiety berdasarkan jenis kelamin. Mean score subjek yang berjenis kelamin laki-laki (54.56) lebih rendah dibanding mean score yang berjenis kelamin perempuan (56.84). Selanjutnya dilakukan uji analisis varians untuk melihat signifikansi perbedaan antara skor mathematics teaching anxiety mahasiswa perempuan dan mahasiswa laki-laki. Hasil pengujian analisis varians dapat dilihat pada tabel berikut.

Tabel 11. Uji Perbedaan MTA berdasarkan Jenis Kelamin

\begin{tabular}{lccccc}
\hline \multicolumn{1}{c}{ MTA } & Sum of square & Df & Mean square & F & Sig. \\
\hline Betwen Grups & 65.520 & 1 & 65.520 & 0.811 & 0.371 \\
Within Grups & 6056.298 & 75 & 80.751 & & \\
Total & 6121.818 & 76 & & & \\
\hline
\end{tabular}

Perbedaan mathematics teaching anxiety antara subjek yang berjenis kelamin laki-laki dan perempuan dapat dilihat pada Tabel 11. Adapun mathematics teaching anxiety antara subjek berjenis kelamin laki-laki dan perempuan tidak memiliki perbedaan yang signifikan $(\rho=0,371>\alpha=0.05)$. Artinya, baik mahasiswa ataupun mahasiswa memiliki tinngkat mathematics teaching anxiety yang tidak berbeda secara signifikan.

\section{KESIMPULAN}

Berdasarkan hasil penelitian dan analisis data dapat disimpulkan bahwa tidak terdapat hubungan negatif antara mathematics teaching efficacy beliefs dan mathematics teaching anxiety pada mahasiswa PPL Program Studi Pendidikan Matematika FTK UIN suska Riau.

\section{PENGHARGAAN}

Terimakasih kepada Lembaga Penelitian dan Pengabdian Masyarakat UIN Suska Riau telah mendanai penelitian ini.

\section{DAFTAR PUSTAKA}

Albayrak, M., \& Unal, Z. A. (2011). The effect of methods of teaching mathematics teaching efficacy beliefs $\mathrm{f}$ elementary pre-service mathematics teachers. International Journal of Humanities and Social Science, 1(16), 183-190

American Psychiatric Association. (2013). Diagnostic and statistical manual of mental disorder (Fift ed.) Arlington, VA: American Psychiatric Publishing, p. 189.

Atkinson, R. L., Atkinson, R. C., \& Hilgard, E. R. (1999). Pengantar psikologi (Ed. 8). Jilid 2. Jakarta: Penerbit Erlangga

Astuti, N. W., Suhandana, I. G. A., \& Dantes, N. (2013). Studi evaluasi efektivitas pelaksanaan praktik pengalaman lapangan (PPL) mahasiswa fakultas pendidikan dan kesehatan (FPOK) IKIP PGRI Bali tahun 2012. E-Journal Program Pascasarjana Universitas Pendidikan Ganesha, 4(1), 1-12.

Behets. D. (I990). Concerns of preservice physical education teachers. Journal of Teaching in Physical Education, 10(1974), 66-75.

Bouras, N., \& Holt. G. (2007). Psychiatric and behavioral disorders in intellectual and developmental disabilities (2nd ed.). Cambridge: Cambridge University Press.

Bradley, R. C. (1984). Taking stress out of student teaching. The Cleaning House, 58, 18-21.

Capel, S. A. (1997). Changes in students' anxieties and concerns after their first and second teaching practice. Educational Research, 39, 211-228. 
Catlioglu, H., Birgin, O., Costu, S., \& Gurbuz, R. (2009). The level of mathematics anxiety among pre-service elementary school teachers. Procedia Social and Behavioral Sciences , 1, 1578-1581, doi:10.1016j .sbspro.2009.01.277

Ennis-cole, D. L. (n.d.). Emerging theories of learning and preservice teachers. Retrieved from http:courses.unt eduF,nnis-Colearticlesa26.pdf

Enoch, L. G., Smith, P. L., \& Huinker, D. (2000). Establishing Factorial of The Mathematics Teaching Efficacy Beliefs Instrument. School Science and Mathematics, 100, 194-202.

Ertekin, E., Dilmac, B., Yazici, E., \& Peker, M. (2010). The relationship between epistemological beliefs and teaching anxiety in mathematics. Educational Research and Review. 5(October), 631-636

Fontana, D., \& Abouserie, R. (1993). Stress levels, gender and personality factors in teachers. British Journal of Educational Psychology, 63, 261-270

Frost, J. B. (2012). Education International Research Institute. Retrieved from http://download.eiie.org/Docs/WebDepot/teacher self efficacy voice eadership.pdf

Furner. J. M \& Gonzalez-dehass. A. (2011). How do students' mastery and performance goals relate to math anxiety?. Eurasia Journal of Afathematics. Science Technology Education, 7(4), 227242.

Hart. N. I. (1987). Student teachers' anieties: four measured factors and their relationship to pupil disruption in class. Educational Research, 29(1), 12.

Hembree. R. (1990). The eature, effect and relief of mathematics anxiety. Research in Mathematics Education, 21(1), 33-46.

Mcbride, R. E. (1981). Perceived teaching and program concerns among preservice teachers, university supervisors, and cooperating teachers. Journal of Teaching in Physical Education, 3, 36-43.

Morton, L. L., Vesco, R., Williams, N. H., \& Awender, M. A. (1997). Student teacher anxieties related to class management, pedagogy, evaluation, and staff relations. British Journal of Educational Psycholology, 67, 69-89.

Ngidi, D. P., \& Sibaya, P. T. (2003). Student teacher anxieties related to practice teaching. South African Journal of Education, 23(1), 18-22.

Peker, M., \& Ertekin, E. (2011). The relationship between mathematics teaching anxiety and mathematical anxiety. The New Educational Review, 23(1), 213-226.

Peker, M., Halat, E., \& Mirasyedioglu, S. (2010). Gender related differences in mathematics teaching anxiety. The Mathematics Educator, 12(2), 125-140.

Preece, P. P. W. (1979). Student teacher anxiety and class-control problems on teaching practice: a cross-lagged panel analysis. British Educational Research Journal, 5(1), 13-19.

Spangler. D. A. (1990). Assessing students' beliefs about mathematics. The Mathematics Educator. $3(1), 19-23$.

Suinn, R. M.., \& Winston, E. H. (2003). The mathematics anxiety rating scale, a brief version: psychometric data. Psychological Reports, 92(1), 167-173

Sullivan, L. (2006). Guided imagery's effects on the mathematics teaching efficacy of elementary preservice teachers. University of New Orleans

Trujillo, K. M., Hadfield, O. D. (1999). Tracing the roots of mathematics anxiety through indepth interviews with preservice elementary teachers. College Student Journal, 33(2), 219-232 
Vinson, B. M. (2001). A comparison of preservice teachers' mathematics anxiety before and after a methods class emphasizing manipulatives. Early Childhood Education Journal, 29(2), 9-94

Wendt, J. C., \& Bain, L. L. (1989). Concerns of preservice and inservice physical educators. Journal of Teaching in Physical Education, 8, 177-180. 